\title{
Two new species of sesarmid crabs (Crustacea: Decapoda: Brachyura) associated with limestone formations in West Papua, Indonesia
}

\author{
DAISY WOWOR ${ }^{1} \&$ PETER K. L. NG ${ }^{2}$ \\ ${ }^{1}$ Division of Zoology, Research Center for Biology, Indonesian Institute of Sciences (LIPI), Jalan Raya Jakarta Bogor Km 46, \\ Cibinong 16911, Indonesia. E-mail: daisy_wowor@yahoo.com \\ ${ }^{2}$ Tropical Marine Science Institute and Department of Biological Sciences, National University of Singapore, Kent Ridge, Singapore \\ 119260, Republic of Singapore.E-mail: dbsngkl@nus.edu.sg
}

\begin{abstract}
Two new species of karst sesarmid crabs of the genus Karstarma Davie \& Ng, 2007, are described from western Papua, Indonesia. Karstarma ardea n. sp. differs from the allied K. ultrapes (Ng, Guinot \& Iliffe, 1994) from the Solomon Islands by its proportionately shorter ambulatory legs and the shape of its vulva. Karstarma waigeo n. sp. is closest to K. balicum $(\mathrm{Ng}, 2002)$ from Bali, Indonesia, but differs in its proportionately longer ambulatory legs and in the morphology of the male first gonopod.
\end{abstract}

Key words: Crustacea, Decapoda, Brachyura, Sesarmidae, Karstarma, new species, Indonesia

\section{Introduction}

As part of its $40^{\text {th }}$ anniversary, the Indonesian Institute of Sciences organized the first e-Win (Ekspedisi Wydia Nusantara) expedition from 27 May to 15 June 2007 to survey the island of Waigeo in Indonesia's West Papua Province. Although rich in marine biodiversity, the terrestrial and freshwater fauna is still poorly known.

Through the kindness of Cahyo Rahmadi, who conducted cave research on the island, several interesting specimens obtained from the karst formations of Gua (= cave) Kalepale and Gua Aleg Afni were passed to us for study. Among the material obtained were two new sesarmid species of Karstarma Davie \& Ng, 2007. Karstarma currently contains 12 species from the West Pacific, all of which are found associated with caves and limestone formations ( $\mathrm{Ng} 2002$; Naruse \& Ng 2007; Davie \& Ng 2007; $\mathrm{Ng}$ et al. 2008).

The terminology follows $\mathrm{Ng}$ (2002), Davie \& Ng (2007) and Husana et al. (in press). The abbreviations G1 and G2 are used for the male first and second gonopods, respectively; CL and CW denote the carapace length and width in millimetres, respectively. Specimens examined are deposited in the Museum Zoologicum Bogoriense (MZB), Indonesian Institute of Sciences, Cibinong, Java; and the Zoological Reference Collection (ZRC) of the Raffles Museum of Biodiversity Research, National University of Singapore.

\section{Systematic account}

\section{Sesarmidae}

\section{Karstarma Davie \& Ng, 2007}

Remarks. There is a problem with the spelling of the name of this genus. In the text of the original description, Davie \& Ng (2007) spelled the name "Karstarma" five times but as "Karstama" nine times; with 
the latter spelling used consistently in $\mathrm{Ng}$ et al. (2008). In the original paper, however, Davie \& $\mathrm{Ng}(2007)$ made it clear that the new name was derived from the word "karst" in combination with "Sesarma". They also spelt it as "Karstarma" when the name was first used (Davie \& Ng 2007: 229). As such, despite the more frequent use of "Karstama", this must be regarded as an erroneous spelling and the correct spelling for the genus must be "Karstarma." This action is to be considered under ICZN (1999) Article 24.2.2 (see also Husana et al. in press).

\section{Karstarma ardea n. sp.}

(Figs. 1, 6C, 7A, B)

Material examined. Holotype: female (34.9 x 28.0 mm) (MZB Cru 2156), Gua Kalepale, Kp. Lopintol, Waigeo, Teluk Manyailibit District, Raja Ampat Regency, West Papua Province, coll. C. Rahmadi \& S. Wiantoro, 31 May 2007. Paratypes: 1 female (23.4 x $19.5 \mathrm{~mm}$ ) (MZB Cru 2157), 1 female (35.0 x $29.3 \mathrm{~mm})$ (ZRC), same data as holotype.

Type locality. Waigeo, West Papua Province, Indonesia.

Comparative material. Karstarma ultrapes (Ng, Guinot \& Iliffe, 1994): 1 paratype female (20.5 x 16.2 mm) (ZRC 1993.7200), Kwakwaru Cave (station 88-087), Basakana Island, off northern Malaita island, Solomon Islands, coll. T. M. Iliffe \& S. Sarbu, 27 August 1988. Karstarma n. sp. from Philippines: 1 paratype female (28.2 x $34.7 \mathrm{~mm}$ ) (National Science Museum, Tokyo, Cr 2007.0103).

Diagnosis. Carapace distinctly trapezoidal in shape, widest between bases of second and third ambulatory legs; anterior regions well defined; dorsal surfaces distinctly rugose, especially on lateral regions, covered with scattered short stiff black setae; deep longitudinal medial groove, lined with inward-curving setae, begins at frontal margin, diverging at meso- and metagastric regions, continuing along lateral margins of cardiac region to form distinct inverted Y-shape; epigastric, postorbital crests swollen, rugose; epigastric crests separated by very deep narrow groove; frontal margin strongly deflexed downwards; supraorbital margin entire, sinuous; infraorbital margin cristate, not meeting supraorbital angle; antero- and distal half of posterolateral margins not demarcated; lateral margin strongly diverging backwards, with 3 distinct teeth including external orbital angle, first, second teeth separated by deep V-shaped cleft, third tooth separated from second tooth by shallow notch, third tooth very low, indistinct. Chelipeds slender, similar in form, equal in size, merus triangular in cross-section, fingers as long as palm, pollex with 2 median longitudinal ridges, cutting edges with numerous teeth, denticles. Ambulatory legs very long, slender; third pair longest; length to width ratios of meri of second, third legs ca. 4.6, 5.5, respectively; outer surfaces of meri, dactyli rugose, margins of dactyli, propodi lined with very stiff long black setae; third ambulatory leg 4.4 times CL, merus 5.4 times CW, 1.5 times CL. Female abdomen very wide; telson distinctly sunken into posterior margin of segment 6; lateral margins of somites 4-6 convex. Vulva complex, with operculum; gonopore surrounded by broad posterior $\mathrm{U}$-shaped elevated projection and a narrow anterior projection, both projections partially cover rounded operculum. Male characters not known.

Etymology. The species name is derived from the Latin genus name for herons (Ardea), alluding to its very long legs. The name is used as a noun in apposition.

Colour. Dorsal surface of carapace, meri and propodi of ambulatory legs bright orange. The carpi and dactyli of the ambulatory legs are white (Fig. 7A, B).

Remarks. In the general form of its carapace and very long ambulatory legs, Karstarma ardea $\mathbf{n}$. sp. closely resembles $K$. ultrapes and a new Karstarma species now being described from the northern Philippines (Husana et al. in press). Their ambulatory leg proportions, however, differ markedly. Although males are not known for $K$. ardea n. sp., male and female specimens are known for $K$. ultrapes and the new Philippines species, and the leg proportions do not differ significantly between the sexes of these $\operatorname{taxa}(\mathrm{Ng} e t$ al. 1994; Husana et al. in press). Karstarma ardea n. sp. has the third ambulatory leg relatively shorter than that of $K$. ultrapes (Fig. 1A) (4.4 times CL vs. 4.9 times CL) but still longer than that of the new Philippines 
Karstarma (4.4 times CL vs. 4.2.times CL). The frontal margin of $K$. ardea $\mathbf{n}$. sp. is also relatively narrower than that of $K$. ultrapes (Fig. 1C vs. Fig. 6A). The structures of the vulvae of these three Karstarma species are also different. Although the general structures of the vulvae of all three species are similar, they differ significantly in the details (Fig. 6B-D).

Distribution. So far only known from the type locality.

\section{Karstarma waigeo n. sp.}

(Figs. 2-5, 6E, 7C, D)

Material examined. Holotype - male (21.9 x 18.9 mm) (MZB Cru 2158), Gua Kalepale, Kp. Lopintol, Waigeo, Teluk Manyailibit District, Raja Ampat Regency, West Papua Province, coll. C. Rahmadi \& S. Wiantoro, 31 May 2007. Paratypes - 1 male (15.4 x $12.8 \mathrm{~mm}), 5$ females (11.1-23.4 x 9.1-19.6 mm), 1 ovigerous female (21.0 x $17.2 \mathrm{~mm}$ ) (MZB Cru 2159), 1 male (20.4 by $17.0 \mathrm{~mm}), 1$ female (22.2 by $17.6 \mathrm{~mm})$ (ZRC), same data as holotype; 1 male (17.5 x $14.4 \mathrm{~mm}), 1$ female (13.8 x $11.0 \mathrm{~mm}$ ) (MZB Cru 2160), Gua Aleg Afni, Kp. Lopintol, Waigeo, Teluk Manyailibit District, Raja Ampat Regency, West Papua Province, coll. C. Rahmadi, 31 May 2007.

Type locality. Waigeo, West Papua Province, Indonesia.

Comparative material. Karstarma balicum: Holotype male (17.8 x $15.4 \mathrm{~mm})(\mathrm{ZRC})$, Gua Giri Putri Cave, 50 m asl, Dusun Karangsari, Desa Suana, Nusa Penida, southeast of Bali, Indonesia, coll. A. J. Whitten, 21 March 1994.

Diagnosis. Carapace approximately trapezoidal in shape; anterior regions well defined, with widely but evenly spaced short setae; lateral regions covered with oblique striae; epigastric region pronounced, divided by prominent groove; frontal margin with concave median emargination; external orbital tooth with tip almost reaching level of frontal margin; outer margin almost straight, separated from first anterolateral tooth by small V-shaped cleft; first anterolateral tooth preceded by small V-shaped cleft; second anterolateral tooth marked by fissure. Chela relatively stout, fingers subequal to length of palm; ventral margin of pollex almost straight. Ambulatory legs relatively long, length to width ratios of meri of second, third legs 3.5, 4.0, respectively; dorsal, ventral margins of merus with weak serrations, dorsal sub-distal edge angular but not spiniform; brushlike setae present on ventral margins of propodus, dactylus of first ambulatory leg, setae sparse on propodus, dactylus of second ambulatory leg, setae absent on third, fourth ambulatory legs; prominent tufts of short setae present between coxae of first to third ambulatory legs. Male abdomen relatively broad, lateral margins of male telson gently diverging backwards. G1 relatively short, stout, with submedian hump along inner margin; distal part sharply bent outwards at approximately right angles, gradually downwards, chitinous distal-most part elongate, straight. Vulva with operculum; gonopore surrounded by broad posterior ovate projection and a small anterior projection, projections tightly appressed against narrow operculum.

Etymology. The species name is derived from the type locality, Waigeo. The name is used as a noun in apposition.

Colour. Brown carapace with propodi and dactyli of the ambulatory legs purplish gray (Fig. 7C, D).

Remarks. Karstarma waigeo n. sp. closely resembles K. balicum $(\mathrm{Ng}, 2002)$ and $K$. loyalty $(\mathrm{Ng}, 2002)$ in having an approximately trapezoidal carapace; the external orbital tooth is not truncate and separated from the first anterolateral tooth by a small V-shaped cleft; and an elongated G1 with a slender chitinous distal part. However, $K$. waigeo n. sp. can be differentiated from $K$. balicum by several characters: the ambulatory leg have longer proportions than in K. balicum (Figs. 2A, 4A) (length to width ratios of meri of second and third ambulatory legs 3.5 and 4.0 respectively; 3.3 and 3.6 respectively in $K$. balicum); the dactylus of the second and the third ambulatory legs are shorter than the propodus (Figs. 2A, 4A) (dactylus is as long as propodus in K. balicum); the G1 is proportionately stout (Fig. 5A-C) (more slender in K. balicum); the inner margin of the G1 has a weak submedian hump (Fig. 5A, B) (almost straight in K. balicum); and the distal part of the G1 has a distinct hump (Fig. 5A-C) (slightly concave or almost straight in K. balicum). 


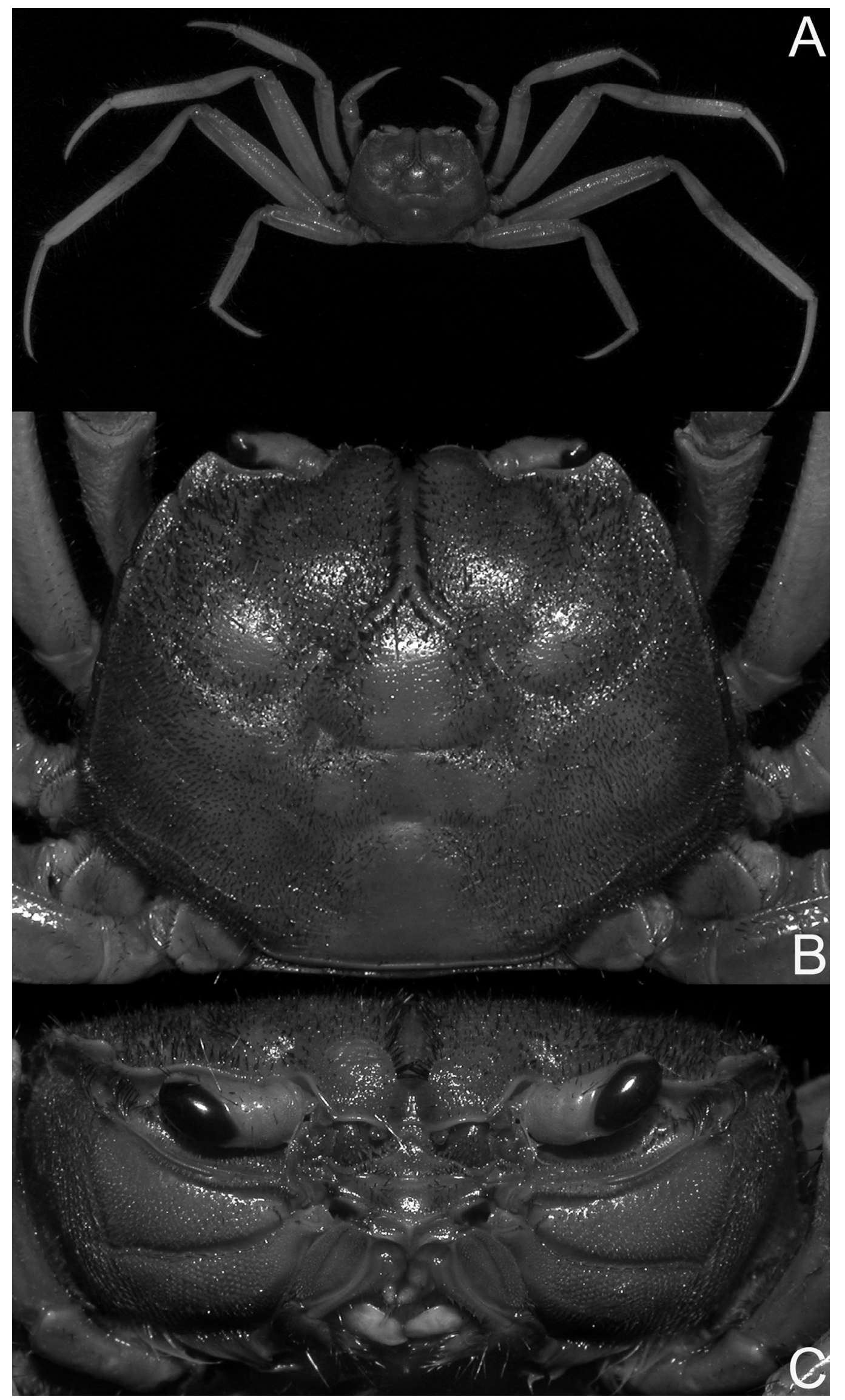

FIGURE 1. Karstarma ardea $\mathbf{n}$. sp., holotype female (34.3 x $28.0 \mathrm{~mm}$ ) (MZB Cru 2156). A, overall view; B, dorsal view of carapace; $\mathrm{C}$, frontal view. 

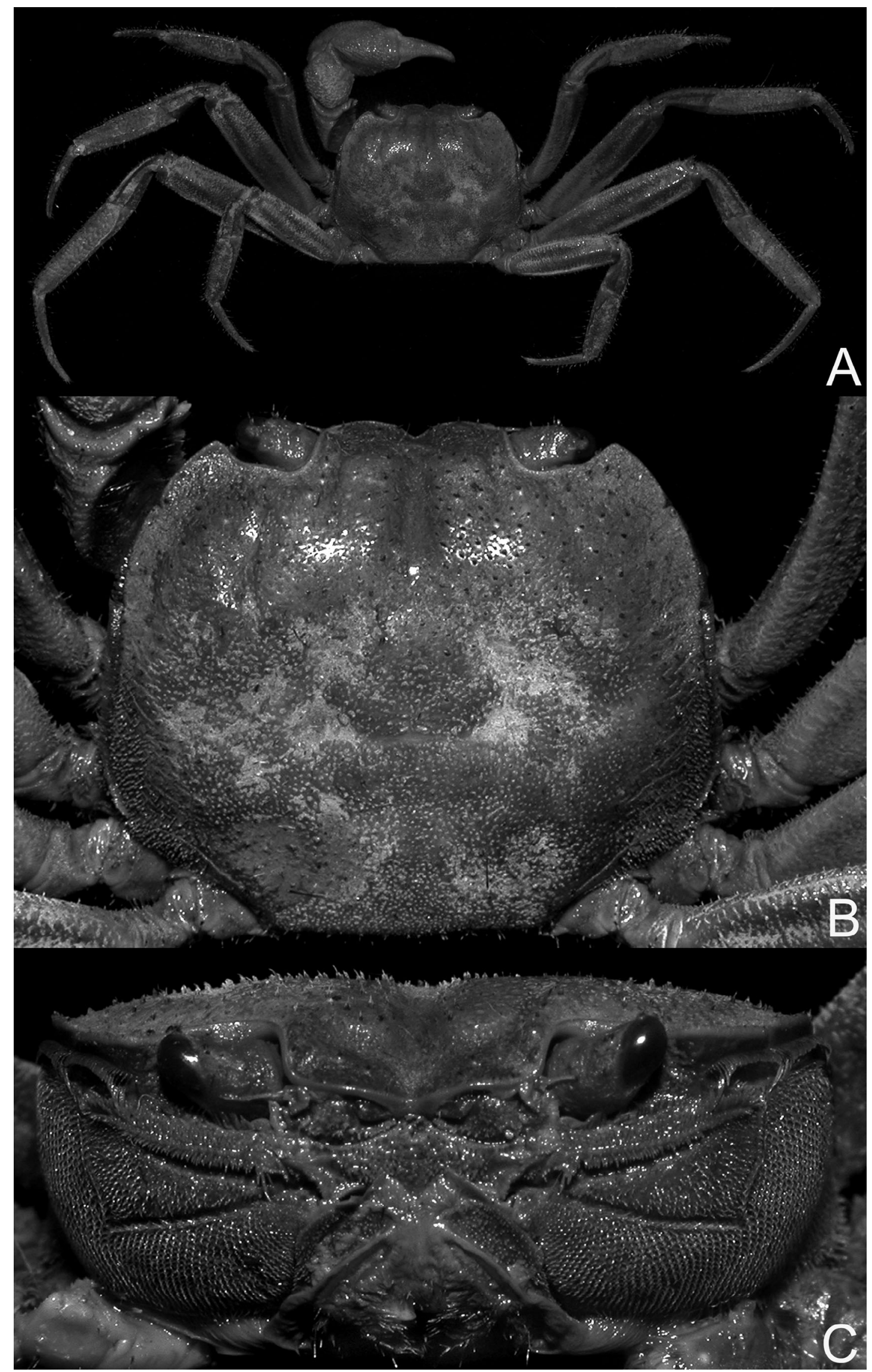

FIGURE 2. Karstarma waigeo n. sp., holotype male (21.9 x 18.9 mm) (MZB Cru 2158). A, overall view; B, dorsal view of carapace; $\mathrm{C}$, frontal view. 


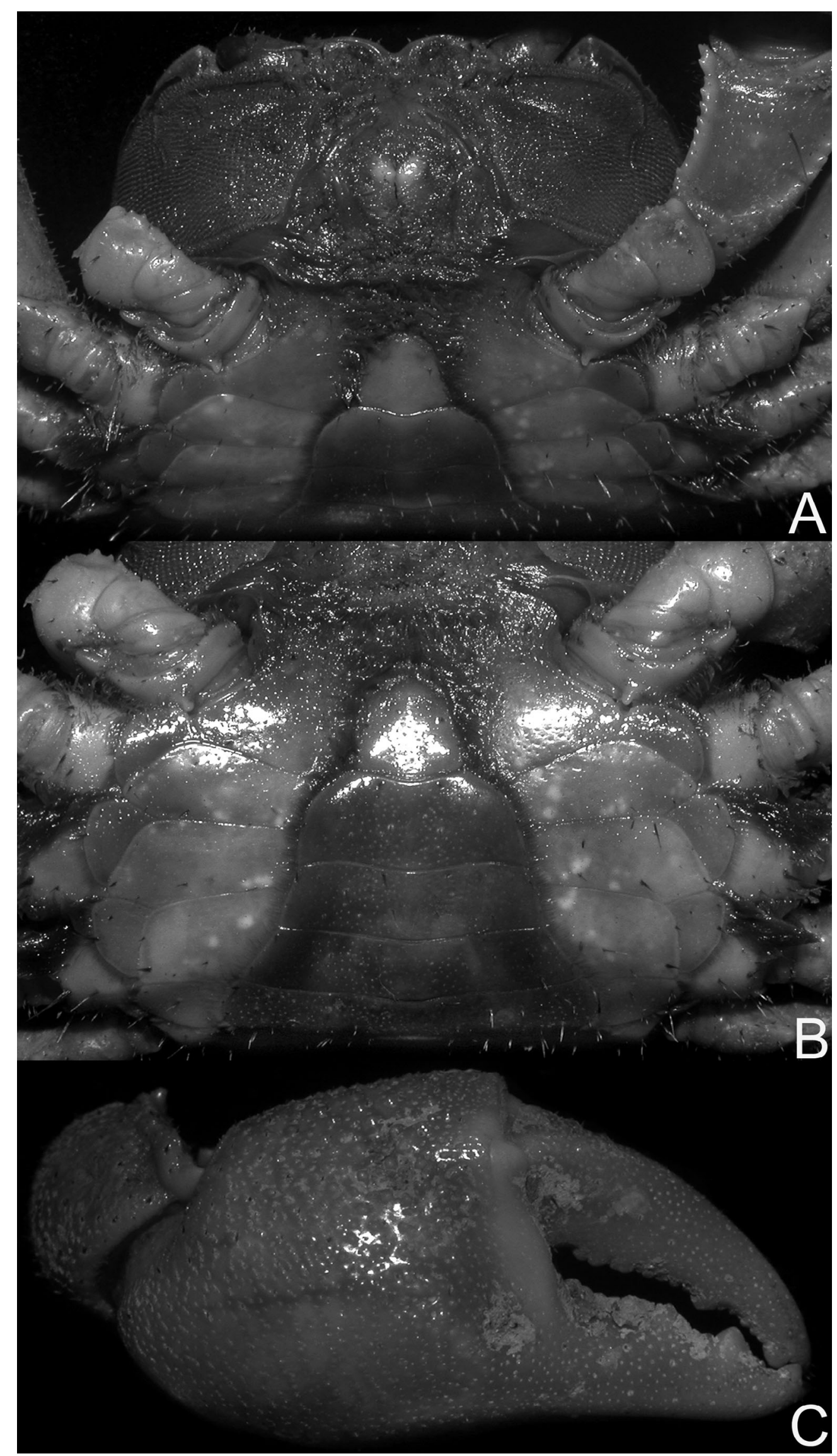

FIGURE 3. Karstarma waigeo $\mathbf{n}$. sp., holotype male (21.9 x $18.9 \mathrm{~mm}$ ) (MZB Cru 2158). A, anterior thoracic sternum; $\mathrm{B}$, abdomen; $\mathrm{C}$, outer view of right chela. 


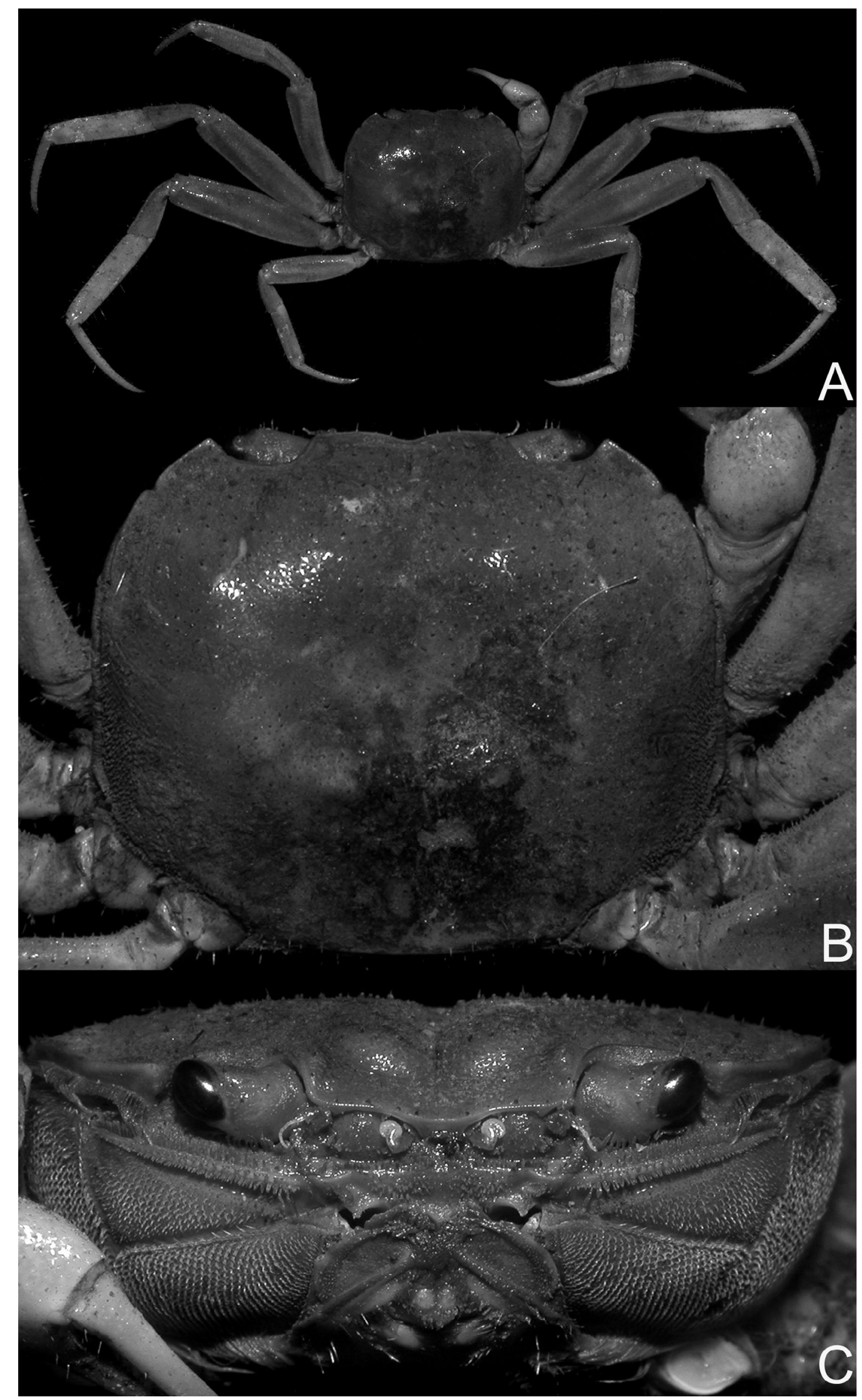

FIGURE 4. Karstarma waigeo n. sp., paratype female (23.4 x 19.6 mm) (MZB Cru 2159). A, overall view; B, dorsal view of carapace; $\mathrm{C}$, frontal view. 

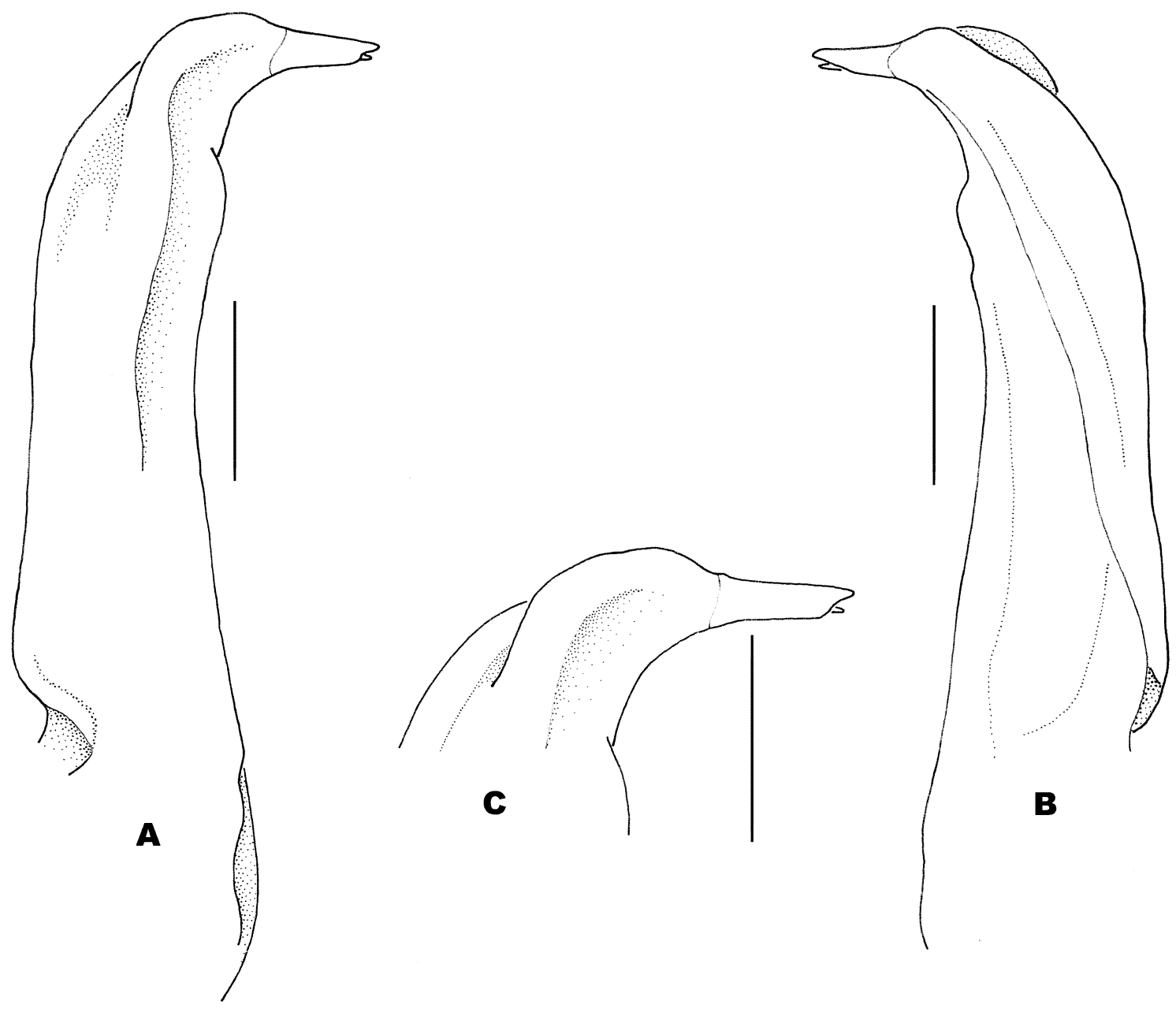

FIGURE 5. Karstarma waigeo n. sp., holotype male (21.9 x $18.9 \mathrm{~mm})$ (MZB Cru 2158). A, G1, ventral view; B, G1, dorsal view; C, tip of G1, ventral view. Scale bars: $\mathrm{A}-\mathrm{C}=1.0 \mathrm{~mm}$.

Karstarma waigeo n. sp. is close to K. loyalty in the morphology of their respective G1, but can easily be separated in having a proportionately longer and more slender G1 structure (shorter and stouter in K. loyalty) and the presence of a distinct hump at the distal part (almost straight in K. loyalty) (Fig. 5A, B). The ambulatory legs are also proportionately longer than in $K$. loyalty (Figs. 2A, 4A) (length to width ratios of meri of second and third ambulatory legs 3.5 and 4.0 respectively, vs. 3.1 and 3.5 respectively in $K$. loyalty), and the dactyli of the second and the third ambulatory legs are relatively shorter than the propodi in $K$. loyalty (Figs. 2A, 4A) (dactyli as long as propodi in $K$. loyalty).

Distribution. So far only known from the type locality.

\section{Discussion}

So far, there are twelve species of Karstarma from various parts of the West Pacific (Davie \& $\mathrm{Ng} 2007 ; \mathrm{Ng}$ et al. 2008). These two new Karstarma taxa from Waigeo in Papua Indonesia, together with the new one from the Philippines now being described by Husana et al. (in press), now raise the total to 15 species.

It is perhaps rather unusual that two very different Karstarma species were found together in the same cave. However, they appear to occupy different habitats; $K$. ardea $\mathbf{n}$. sp. was found at the rocky parts of the cave, while $K$. waigeo n. sp. preferred the muddy substrates (C. Rahmadi, pers. comm.). The only other such case is with $K$. emdi (Ng \& Whitten, 1995) and K. balicum $(\mathrm{Ng}, 2002)$ on the island of Nusa Penida in Bali. In the latter case, the species are more similar. Explorations of other caves of Waigeo did not uncover any Karstarma species. 
It is noteworthy that are in fact two general types of morphology among the species of Karstarma. Members of one group of species (as exemplified by $K$. waigeo $\mathbf{n}$. sp.) have an approximately trapezoidal carapace, the third ambulatory leg is less than four times the CL, the distal part of the G1 is sharply bent outwards at approximately right angles (see $\mathrm{Ng}$ 2002), and most significantly, the vulva is formed by a large ovate posterior projection and a small anterior projection, with the projections tightly appressed against the narrow operculum (Fig. 5E). Members of the second group of species (as exemplified by K. ardea $\mathbf{n}$. sp.) have a distinctly trapezoidal carapace, the third ambulatory leg is more than four times the CL, the distal part of the G1 gently bent outwards at an angle of about $30-40^{\circ}$, and significantly, the vulva is formed by a large Ushaped posterior projection and a prominent anterior projection, with both projections partially covering the prominent rounded operculum (Fig. 5B-D). Interestingly, the vulvae of species of Sesarmoides Serène \& Soh, 1970 sensu stricto, where most Karstarma species had previously been placed, is very simple, consisting of just a simple operculum and a slightly raised posterior margin (Fig. 5F). These observations suggest that the generic affinities of the species group with a distinctly trapezoidal carapace and very long ambulatory legs need to be seriously re-examined.

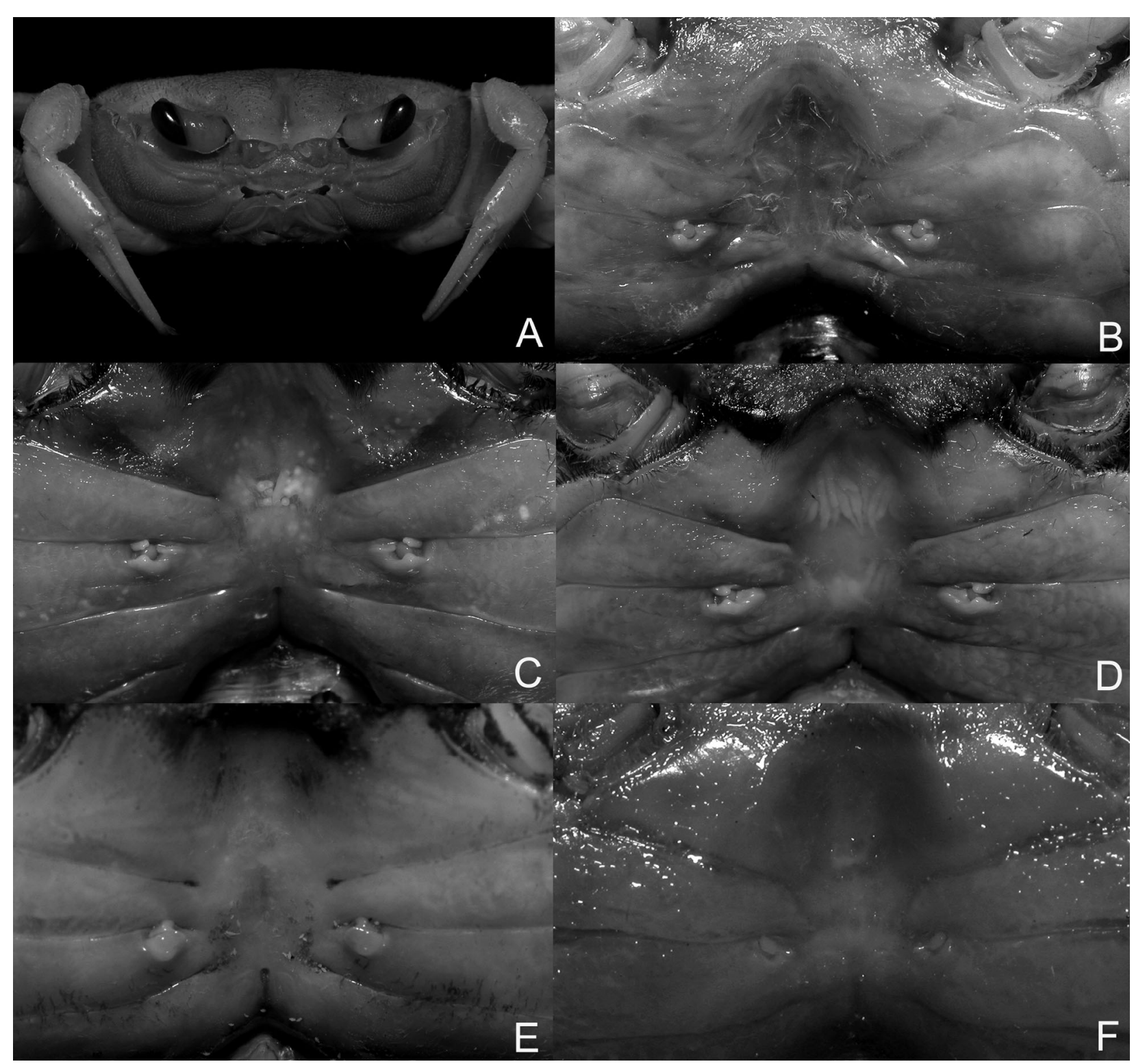

FIGURE 6. A, B, Karstarma ultrapes, paratype female (20.5 x 16.2 mm) (ZRC 1993.7200); C, Karstarma ardea $\mathbf{n . ~ s p . , ~}$ holotype female (34.3 x $28.0 \mathrm{~mm}$ ) (MZB Cru 2156); D, Karstarma n. sp., paratype female (28.2 x $34.7 \mathrm{~mm})(\mathrm{National}$ Science Museum, Tokyo, Cr 2007.0103); E, Karstarma waigeo n. sp., paratype female (23.4 x 19.6 mm) (MZB Cru 2159); F, Sesarmoides borneensis, paratype female (18.1x 15.4 mm) (ZRC 1964.9.8.5-6). 


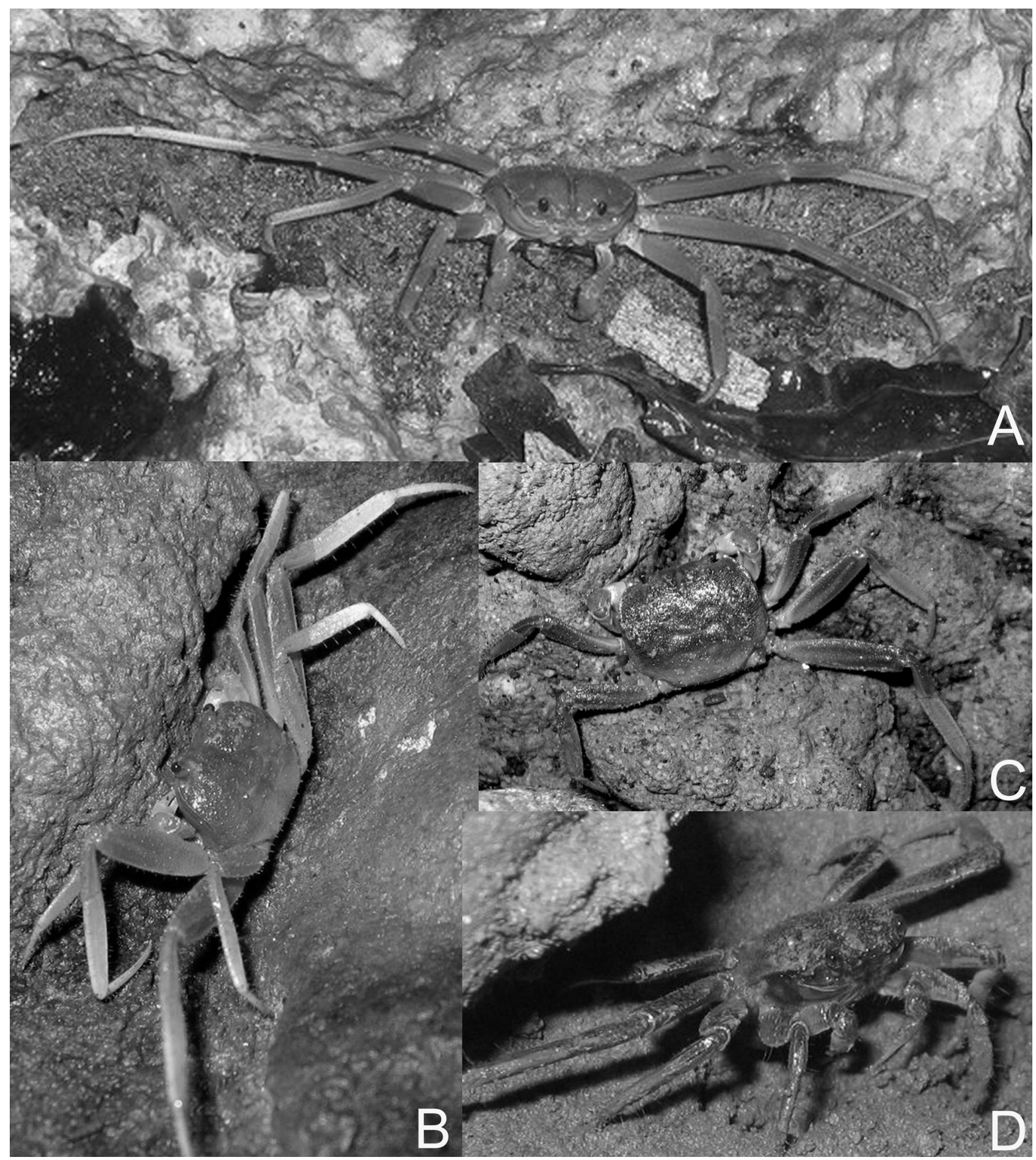

FIGURE 7. Colours in life. A, B, Karstarma ardea n. sp.; C, D, Karstarma waigeo n. sp. A, Triton Bay, West Papua Province, Indonesia, by A. Tay, 2006 (specimen not collected); B-D, Gua Kalepale, Waigeo, Raja Ampat Regency, West Papua Province, Indonesia, by C. Rahmadi (specimens not collected).

\section{Acknowledgements}

The authors thank Cahyo Rahmadi for collecting these interesting specimens for us and providing colour photographs. We also thank Andrew Tay who provided us with his excellent photograph of $K$. ardea for use in this paper. Tohru Naruse kindly passed us specimens of his new Philippine species for comparisons. Thanks 
are also due to Colin McLay and Peter Davie for their many constructive suggestions, particularly pertaining to the structure of the vulva.

\section{References}

Davie, P. J. F. \& Ng, P. K. L. (2007) A new genus for cave-dwelling crabs previously assigned to Sesarmoides (Crustacea: Decapoda: Brachyura: Sesarmidae). Raffles Bulletin of Zoology, Supplement 16, 227-231.

Husana, D. E. M., Naruse, T. \& Kase, T. (in press) A new species of the genus Karstarma (Decapoda: Brachyura: Sesarmidae) from anchialine caves in the Philippines. Raffles Bulletin of Zoology.

ICZN (1999) International Code of Zoological Nomenclature. International Commission of Zoological Nomenclature. Fourth Edition. Adopted by the XXI General Assembly of the International Union of Biological Sciences. International Trust for Zoological Nomenclature, in association with the British Museum (Natural History), London, $338 \mathrm{pp}$.

Naruse, T. \& Ng, P. K. L. (2007) On a new species of cavernicolous crab of the genus Sesarmoides Serène \& Soh, 1970 (Crustacea: Decapoda: Brachyura: Sesarmidae) from Sulawesi, Indonesia. Raffles Bulletin of Zoology, 55(1), 127-130.

Ng, P. K. L. (2002) New species of cavernicolous crabs of the genus Sesarmoides from the western Pacific, with a key to the genus (Crustacea: Decapoda: Brachyura: Sesarmidae). Raffles Bulletin of Zoology, 50(2), 419-435.

Ng, P. K. L., Guinot, D. \& Davie, P. J. F. (2008) Systema Brachyurorum: Part I. An annotated checklist of extant brachyuran crabs of the world. Raffles Bulletin of Zoology, Supplement 17, 1-286.

Ng, P. K. L., Guinot, D. \& Iliffe, T. M. (1994) Sesarmoides ultrapes new species, a remarkable sesarmine crab from caves in the Solomon Islands (Decapoda: Brachyura: Grapsidae). Crustacean Research, 23, 12-22.

Ng, P. K. L. \& Whitten, A. J. (1995) On a new cave-dwelling Sesarmoides (Crustacea: Decapoda: Brachyura: Grapsidae) from Nusa Penida, Bali, Indonesia. Tropical Biodiversity, 1994, 2(3), 369-376.

Serène, R. \& Soh, C. L. (1970) New Indo-Pacific genera allied to Sesarma Say, 1877 (Brachyura, Decapoda, Crustacea). Treubia, 27(4), 387-416. 